\title{
The Bahamas in International Intrigue: Lighthouses and Cay Sal Bank
}

\author{
Jim Lawlor \\ Vice President and Past President of The Bahamas Historical Society \\ Nassau, Bahamas
}

\section{Abstract}

In the early 19th century the expansion of the United States of America westward required increased trade from the ports on the Eastern Seaboard to their new ports in the Gulf of Mexico. The journey of the sailing ship through the dangerous and poorly charted channels of the islands of The Bahamas and down the Gulf of Florida into the Gulf of Mexico resulted in many wrecks and financial loss. The United States Congress requested the government of Great Britain to cede land in The Bahamas to them to build lighthouses to aid navigation through the channels. Britain, wary of allowing her recent enemy to occupy strategic positions within The Bahamas, refused and decided to erect lighthouses by British companies. A further complication was that one of the locations, the Cay Sal Bank, was at that time under dispute of ownership between the Spanish Colony of Cuba and the British colony of The Bahamas.

\section{Introduction}

By the early 19th century after a series of wars with France, Spain and the United States of America, Britain jealously guarded every inch of her West Indian colonies. The United States of America's request for cession of strategic plots of land in The Bahamas for lighthouses was considered by Britain with mistrust. Relations between Britain and its former colony had been strained since the War of Independence and the War of 1812. The ideology of the Monroe Doctrine sought to expand United States territory and economic power but Britain did not want that expansion to be into her sovereign territory.

Of further concern to Britain was that one of the areas requested, the Cay Sal Bank, of strategic importance to the United States of America, was at the time contentiously claimed by both the British colony of The Bahamas and the Spanish colony of Cuba.
This article describes the dangerous routes to be taken by sailing ships, the necessity of lighthouses and the international intrigue between Britain and America as to which country should erect the lighthouses in The Bahamas. Further it reveals the intrigue between Spain and Britain as to the whether the Cay Sal Bank belonged to Cuba or The Bahamas and the position the lighthouse should be erected.

The lack of accurate charts and navigational aids made conditions difficult for captains sailing new trade routes. Birse Shepard in Lore of the Wreckers (1961) describes how the captains of sailing ships found their way:

Sea-borne commerce was the lifeblood of the early Colonies - windjammers were sailing up and down the coast through the Bahama passage and Florida straits with scant knowledge of where they were going or how they would get there. Their skippers kept their 
reckoning with chalk on a shingle....and by way of observation they held up a hand to the sun. When they got him over 4 fingers they knew they were straight for Hole-in-the-Wall; 3 fingers gave them their course to Double Headed Shot cays and 2 fingers carried them down to Barbados (p. 54).

Shepard further details the difficulties of navigation in those early days:

Trained navigators were rare and Captains used a magnetic compass and inaccurate charts. They figured latitude with a cross staff by angular distance from the celestial equator. Ships ran aground innocently on hidden rocks and shoals, turned turtle because of clumsy or careless loading, sunk down in gales, were lost through ignorant or faulty handling, casualties were due to ignorance, incapacity or carelessness of crews and masters. Sound vessels were overwhelmed by sudden squalls, ran aground because the compass was disturbed by a difference between magnetic and true north. There were many fraudulent disasters when owners or masters wished to exchange worthless worn-out vessels for financial gain ( $p$. 4).

The British government was the first to recognize the need for lighthouses to assist captains to navigate the most treacherous areas of Bahamian Seas. The first lighthouse in The Bahamas was the 69 foot tall Hog Island lighthouse (now Paradise Island), which could be seen from a distance of 13 nautical miles, was commissioned in September 1817. Lord Dunmore may have thought of a lighthouse there when he reserved the western point of Hog Island as Crown Land. From 1794 a lantern had been affixed to the northern angle of Fort Fincastle but the light was a mile away from the entrance to the harbour and of low intensity. In May 1816, plans and specifications for a lighthouse were prepared by Alexander McBride and James Wood won the bid for tender. The limestone tower took nearly a year to build and an octagon lantern imported from England. On the evening of September 1, 1817 the light shone out for the first time (Albury, 1984). It is interesting to note that a phial containing coins, medals and a legend recording the date and important incidents of the commencement of the structure were placed in a cavity under the corner stone (Albury, 1984).

After the Spanish ceded Florida to the United States of America in 1819, the United States built a naval settlement at Key West with a view to securing safe passage of their trading vessels through the Gulf Stream into the Gulf of Mexico. Further, due to the increasing number of wrecks on the treacherous shoals throughout The Bahamas, the United States government sought to establish lighthouses at strategic points in the channels (Figure 1). On December 24, 1824, United States President James Monroe communicated the following message to the House of Representatives:

In compliance with a resolution of the House of Representatives of the 23rd December 1823, requesting that a negotiation should be opened with the British Government "for the cession of so much land on the island of Abaco at or near Hole-in-the-Wall, and on such other places within the acknowledged dominions of that power on the islands, keys or shoals of the Bahamas Banks as may be necessary for the erection and support of lighthouses, beacons, buoys, or floating lights for the security of navigation over or near the said banks and used solely for that purpose," directions were given to the Minister of 
the United States at London on the 1st January 1824 , to communicate the purport of that resolution to the Government of Great Britain with a view to their acceding to the wish of this; and I transmit to the House copies of $\mathrm{Mr}$. Rush's correspondence upon this subject, communicating the result of his application to the British Government (Richardson, 1897, p. 845).

The Louisiana Purchase in 1803 and the acquisition of Florida fueled American industrial expansion. The newly acquired ports in the Gulf of Mexico could only be accessed by sailing ships before the time of inter-connecting roads and railways. Farm produce, lumber and livestock from inland states were loaded on flatboats and carried down the rivers and streams to the Mississippi and then south to New Orleans. At that port everything was transferred to coastal sailing vessels, which carried cargoes across the Gulf of Mexico, around Florida and up the coast to the eastern seaboard cities - or even to Europe. On the return voyage large ships sailed east of Abaco, through the Hole-in-the-Wall channel, continued on to Sturrup's Cay then entered the Gulf by the North West Providence Channel around the Great Isaac's Rock. Smaller ships to Sturrup's Cay could pass over the Great Bahama Bank until they got south of Cat Cays and sometimes Orange Cays, when they entered the Gulf (CO23/77/5, 1827, October 15). Some brave or fool-hardy American captains, in the interest of time, took the more dangerous route around the north of Walker's Cay, North Abaco and into the Gulf, sometimes stopping for a pilot at Green Turtle Cay. This new growth in commerce across the Bahamian waters led to an increase in wrecks at the notably dangerous spots: the wind-ward coasts of North Eleuthera, Harbour Island and Abaco, Great Sturrup's
Cay, the Gingerbread Grounds, the Bimini Cays and the west end of Grand Bahama (Lawlor \& Lawlor, 2008). Hence the demand for lighthouses in these key areas.

In March 1824, Bahamian Governor Grant asked the British Government to protect against any attempts of the American government to control the passage between Abaco and Eleuthera and the entrance to the Gulf Stream. The British Naval Commander, Captain Porter questioned whether Britain would be prepared to erect lighthouses and suggested locations at Holein-the-Wall, Bimini, Double Headed Shot Cays and Buoys from Sturrup's Cay to Orange Keys. He reported the claim by Cuba that the Cay Sal Bank was a possession of Spain. But Grant asserted that there was a compromise in 1802 between Governor John Halkett and the Cuban Governor that Bahamians could wreck and turtle on the Cay Sal Bank and Cubans could rake salt (CO23/73/23, 1824, March 4). Grant further observed that Key West (Thompson's Island) was directly opposite Havana and was a naval depot and a rendezvous for the American Squadron, and he believed the American bid to possess the Cay Sal Bank to be a trick (CO23/73/104, 1824, March 4).

Governor Grant after consultation with Admiral Fleming recommended that the American proposition should on no account be considered as Key West, due north of Havana contained a naval base and a Vice Admiralty Court. It was the principal rendezvous of the American Squadron on the West Indian and Mexican stations. In addition, the Americans were contemplating a naval station at Pensacola. In case of war, Key West and Cay Sal would have advantages for protection, would be a rendezvous for steam war vessels and an ideal location for launching an attack of Jamaican convoys to and from Britain. 
Grant recommended that Britain should declare the right to Cay Sal Bank against the pretentions set forth by the Governor of Cuba (in a letter to Admiral Fleming), who had also been approached by the American government for a footing on Cay Sal. The Keys on the Bank were, from a production point of view, good for nothing, with the exception of Cay Sal which was capable of conversion into a large salt establishment with an excellent anchorage. Also it was important for all trade passing through the Gulf of Florida from Jamaica, Honduras, Mexico, West Florida and Havana (CO23/76/411, 1827, December 22).

After the 1812 War with the United States, Britain sought to safeguard her possessions in the West Indies and sent out naval teams to survey and fortify them. Realizing that the positions for the lighthouses were in key areas to assist trading vessels in peacetime and naval vessels in time of war, the recommendation of British Naval Commander Anthony de Mayne to the Admiralty was:

I beg leave respectfully to address you for the information of His Royal Highness the Lord High Admiral on the subject of erecting Lighthouses that is now in contemplation to be placed in the North West Bahama Channel as well as on the different Keys on the Bahama side of the Gulph of Florida, and wish respectfully to state my reasons in pointing out to his Royal Highness the most eligible situation they should be erected, so as to be the most beneficial to the Navigation in general, also to point out every other information respecting the Building as far as the local knowledge \& experience I have gained on being employed upwards of 12 years in surveying the Bahama Islands.
These few years past almost all the trade from the North part of America as well as all Europe trading to the Island of Cuba or the Ports in the Gulf of Mexico have passed through the North East Bahama Channel which is formed by the Southwest point of the island of Abaco called the Hole in the Rock and Egg Island on the opposite side the distance across being a little more than twenty one miles.

They then sail over the Bahama Bank or through the North West Bahama Channel as occasion may require $\&$ by sailing along the Bahama side of the Gulf of Florida, they are enabled to avoid the Gulph Stream and thereby make a shorter route, and very quick returns. My reasons for pointing out the south west point of Abaco as a most desirable place for the erection of a Lighthouse is that in a political point of view that in the event of carrying on offensive operation; on the southern coast of America it will be forced to be one of the most important passes amongst the Bahama Islands to prevent all intercourse with the Gulf of Mexico through this quarter.

The Land about the extreme point of Abaco or Hole in the Rock forms a high commanding situation for a Lighthouse compared with the rest of the Bahama Islands. The highest part or Hill is about sixty feet above the level of the Horizon and the surrounding land is so formed by nature that it may be easily fortified if required. There is good anchorage under the point for ships of any class about three quarters of a Mile from the shore where they lay sheltered from the North to the Southeast winds which are the prevailing winds on this Coast. 
From the nature of the Bahama Islands affording no universal substance the erecting of Lighthouses would be expensive as the rock is calcareous and the soft for building in consequence of which all the materials for the purpose must be sent from England except wood and lime. I should think to the best of my judgment that it would cost Five Thousand Pounds to erect a Lighthouse on this point and this estimate may in some measure be a guide for the rest, without they are built of the stone of Islands.

The second position to erect a Lighthouse is on the West end of the Grand Bahama in Latitude 26 degrees 42 minutes North as this part of the island if inhabited and plenty of wood and fresh water to be procured a Lighthouse may be built at a much less expense than that on the south west point of Abaco. It would enable HM's Cruisers to keep their stations \& be great acquisition to our homeward bound trade.

The third position for a Lighthouse is on a small high Key called Gun Key, situated on the Gulf of Florida East side in Latitude 25 degrees 25 minutes North it affords no fresh water but has a good harbour to land the necessary stores. This point would also be a great acquisition to HM's Cruisers as well as the mercantile trade by giving them a good departure soon after which they would be through the Gulf of Florida.

The fourth situation for a Lighthouse is on one of the Elbow Keys called the Double Head Shot Keys which forms the south western boundary of the Key Sal Bank. This Key is situated in Latitude 23 Degrees 56 minutes North and Longitude 80 degrees 24 minutes west it is a large half mile in length $\&$ about six hundred yards in breadth at the broadest part. It affords no wood or fresh water \& it exposes a sharp rocky surface towards the Sea, particularly on the Gulph side. About the middle of the Key, which is the widest part, it forms a high hill about thirty feet above the level of the Sea with a sufficient base to erect a Lighthouse \& other buildings for its support.

A Lighthouse on this position would also enable HM's Ships to prevent all intercourse through the old Bahama Channel, and it would also in my opinion, be a great check to the Slave Ships which generally pass through these rocks on their way to the Havana \& the adjacent ports. The Merchant Ships are very often imperceptibly drawn down on the Florida Keys and reef when passing through the Gulf, by not taking their departure from these Rocks \& a number of Wrecks is the consequence.

I beg humbly to state that the before mentioned Lighthouses would be fully sufficient in my opinion to answer every purpose for navigating through the Gulf of Florida (CO23/77/5, 1827, October 15).

The Americans took good care of their side of the Gulf; by 1826, the first three lighthouses were completed: one at Key West, another at Sand Cay marking the main ship channel around Key West and into the Gulf of Mexico, and a third at Cape Florida, near present day Miami. A single lightship, the Florida was built at the same time to warn shipping off the Carysfort Reef, the most dangerous spot on the coast (Shepard, 1961).

In September 1827, Sir George Murray of the Vice Admiralty reported that: 
an American Schooner Grampus has lately been cruising off the west end of Abaco upon the pretext of looking for a rock on which an American ship struck. I believe the real reason was to look for a place for a lighthouse on a cay, which was not occupied (CO23/78/193, 1827, September 3).

A letter from Admiral Fleming added:

I likewise know that a Sloop of War of that Nation (United States of America) was for many days on the Key Sal Bank, sounding \& making observations; and the officers made no secret at the Havana of the intention of their Government to occupy one of the Keys, for the purpose they said of erecting a light house (CO23/76/421, 1827, September 6).

In October 1827, Governor Grant reported to England that the trade of The Bahamas colony was diminishing and, in consequence, urged Britain to place the port of Nassau on the same footing as Halifax and Saint John, New Brunswick and, like them, be made a port of deposit. He reminded them that Nassau lay in the direct route between all the old States of America on the one hand, and Cuba, Louisiana, and Mexico, on the other. It also was conveniently located between Jamaica and America. Therefore, the dangers of the Bahama Banks would induce the American Vessels to deposit produce in Nassau rather than proceed to Havana (CO23/76/303, 1827, August 12).

Grant also observed that the locality of The Bahamas had become much more important and interesting in consequence of changes in the hemisphere. Columbia, Mexico, Louisiana, Cuba and Florida used to belong to Spain but the case was now different. Along with Jamaica and Honduras they were now trading with Europe and the old States of America and obliged to pass through the passage of the Gulf of Florida which washed the Bahama Bank (CO23/76/303, 1827, August 12).

Grant referred to Correspondence which implied:

an understanding between the Governors of Cuba and the Bahamas which permitted the Inhabitants of the Island of Cuba to visit Key Sal in the Salt Season and to rake salt, on condition that the fishers \&c of the Bahamas should not be [stopped from] fishing and turtling on the Coast of Cuba That such an understanding had been expressly made is the universal belief of the inhabitants of the Bahamas, and so generally have I been told it that I cannot doubt it, although I can find no record to this effect. It is said to have taken place in Gov. Halkett's time (1802-1806) and as $\mathrm{W}$. Halkett is now in one of the public offices in London, I have every reason to think he can give some explanation of the matter.

At all events Governor Vives' assumption that Key Sal Bank is the property of Spain is but a very recent occurrence, if it has arisen, as it would appear to have done, in the application made to him by the Government of the US for information if there was any objection to Lighthouses being placed on one of the Keys in the Bank, and even if such application did amount to anything, it is counterbalanced by a like application having come to me at some time and through the same Channel (CO23/76/411, 1827, December 22).

Governor Halkett had no record of such an agreement on the Cay Sal Bank nor could records be found in London. So Governor Grant had Justice John C. Lees take sworn statements from seven of the old inhabitants. 
John Bunch of New Providence, 80 years old, to his recollection, the Key Sal Bank was always deemed and considered part of the Bahamas. To his best of belief about the year 1761 when William Shirley was Governor, 3 turtling vessels belonging to the inhabitants of the Bahamas, one or two of them belonging being the property of Thomas Bunch, his uncle now deceased were seized by the Spanish Guarda Costa, and arrived in the Port of Havana, that from the fact being made to Governor Shirley, he requested James Wallace esq the commander of one of the Sloops of War to the said Port of Havana, for the purpose of procuring of the said turtling vessels. That they swear positively as to the Sloop of war was called the Bonita, Mr. Wallace did proceed to the said Port of Havana and that the said turtling vessels were given up and restored. The deponent understood in consequence of the agreement or understanding, which had been entered into or existed between the Captain General of Cuba and the Governor of the Bahama Islands that in the privilege given by the Governors to Spanish vessels are permitted to rake and carry salt from Key Sal, in consequence of the British having permission to wreck and turtle on the said Islands of Cuba (CO23/83/13, 1829, July 30).

Joseph Thrift, aged, 60, William Moody Pinder, aged, 76, Joseph Thompson, aged, 57, Benjamin Griffin, aged, 67, Nathaniel Sweeting, aged, 53, and Robert Price, aged, 76, a free man of colour, all mariners of New Providence:

Being severally sworn - all remembered vessels belonging to the inhabitants of the said Bahama Islands permitted to wreck and turtle off the East Coast of Florida until the cession of that province by His Catholic Majesty to the United
States of America and to turtle on the Coast of Cuba. They always understood and believed the agreement and that the Key Sal Bank belonged to the Bahamas' Government $\quad(\mathrm{CO} 23 / 83 / 15, \quad 1829$, September 10).

Governor Grant conceived that if the Cay Sal Bank was important to the British government, they should build a battery or lookout house on Cay Sal. The building would declare the British right and oppose the possible residence of Americans there. He mentioned the case of a shipwreck on the Cay Sal Bank at Dog Keys. An American brig took the most valuable part of the cargo to Key West. The crew of the American brig prevented the Bahamian sloop Enterprise from working on the wreck and drove them away with force. Grant further thought that although this incident was the act of individuals, it might in the future be looked upon as a precedent to prove that the Bank and Keys were common property. Grant stated: "What I chiefly wish to impress is, that America wishes in some way, or other, to obtain a footing on Key Sal Bank and that my opinion is, that we should decidedly, forever, put her views and expectations at rest" (CO23/76/419, 1827, June 29).

Admiral Fleming agreed with Governor Grant,

The Establishment proposed by the Major General on the Key Sal Bank would be most highly advantageous in the suppression of piracy and the slave trade, as well as useful in affording protection for the Crews of any vessels, which may be wrecked there, which very frequently happens, and it might be made as a temporary Depot for part of the Cargoes saved which are now often plundered or lost (CO23/76/422, 1827, September 3). 
Furthermore, Admiral Fleming believed that despite the claim to the Cay Sal Bank of Cuban Governor Vives, the King of Spain had ceded it to His Majesty. And because the possession of Cay Sal was important to the trade of the Bahamas he would provide a Naval Force to protect it (CO23/76/423, 1827, December 1).

In February 1828, Acting Governor William Vesey Munnings informed Sir George Murray that, "His Majesty's Government has undertaken to erect Lighthouses on Double Headed Shot Cays, which is now more important because of American possession of Florida" (CO23/81/224, 1828, February 18). In December 1833, John Kitson of the Royal Engineers' Office received instructions to proceed to Havana and explain to the Governor of Cuba that the purpose of his visit was to prepare plans for lighthouses to be erected along the Gulf of Florida including the Double Headed Shot Cay (CO23/91/14, 1833, December 27).

In June 1834, British Consul, George Villiers in Madrid wrote to the Spanish Prime Minister Don Francisco Martinez de la Rosa to explain that preliminary steps for erecting lighthouses had begun but the lighthouse at the Double Headed Shot Cay had been suspended due to Cuba's claim to that Cay (CO23/92/266, 1834, June 26). Villiers transmitted to Lord Viscount Palmerston, the reply of Don Francisco Martinez de la Rosa, who stated that:

orders have been issued to the captain General of Cuba for the erection of the lighthouse not only on the spot mentioned but on any other where it may be considered necessary for the safety of navigation; the expenses which are borne by the Royal Treasury of Havana as the Spanish Government confirm the claim set up by the Captain General of Cuba to Cay Sal Bank as a dependency of that
Island (CO23/92/263, 1834, November 8).

Villiers begged Martinez de la Rosa to:

understand the ultimate decision of the point was to be in no way prejudiced by the lighthouse being established there at the expense of Spain, but that the matter should stand as it would have done if the lighthouse had been built at the expense of Great Britain, and assurance offered in my note of 3rd inst. been given by His Majesty's Government. Don Francisco Martinez de la Rosa said he considered this perfectly fair and that he was quite content to leave the question as I proposed $\quad(\mathrm{CO} 23 / 92 / 263, \quad 1834$, November 8).

The Bahama Argus of November 15, 1836, in a Notice to Mariners, announced the completion of the lighthouses at Hole-in-theWall, Abaco and Gun Cay on the Western edge of Grand Bahama Bank (CO23/102/25, 1836, November 15). Both were built by Great Britain.

The situation concerning the lighthouse at Cay Sal Bank was completely different.

In November 1835, Lt. Commander Hornby of the British navy reported to Governor Colebrooke that while approaching Cay Sal he saw Spanish colour hoisted and met a garrison of Spanish Navy consisting of a Commander, a Lieutenant and 22 soldiers with a Guardhouse and 27 thatch huts. They had immense quantities of salt for shipping and were growing cotton, corn and vegetables. "There was not a symptom of preparation for the building of a lighthouse" (CO23/94/233, 1835, November 13).

Hornby's report brought about a flurry of concerned letters to and fro between the two nations. The British Consul in Madrid, George Villiers, writes to Spanish Minister, in strong words: 
The Spanish Authorities, when the Rights of humanity were concerned have been disobedient or indifferent to the orders which the Spanish Minister solemnly assured me, had been sent out, but in a case which involved Rights of Property, they have shown no activity but negligence or violating them.

With regard to the first point, the erection of the lighthouse, I have to express the just concern of my Government.

The confidant expectation of his Majesty's Government that orders will be given immediately to the Captain General of Cuba to withdraw Spanish settlers and soldiers, and to leave the bank exactly in the same state as hereforto (CO23/95/72, 1835, November 24).

When British naval Captain J. L. Willis anchored at Cay Sal Bank in April 1836, the garrison had been withdrawn, four men were raking salt, there was no preparation for a lighthouse but a Spanish merchant flag was hoisted on Cay Sal (CO23/96/427, 1836, April 28).

When the Captain General of Cuba did make a contract with an American construction company to construct the lighthouse, British navy surveyor and Captain Richard Owen found it to be in the wrong location.

The position selected for the erecting of a lighthouse on Cay Sal Bank, viz the South extreme of Cay Sal is so highly objectionable as connected with the navigation of the Gulf of Florida that I feel assured that it only requires me to point out to Your Excellency to induce you to shift the position originally fixed by the British Government for the site of the proposed lighthouse viz on the Elbow Cay of the Double Headed Shot
Cays about 14 miles to the NW of Cay Sal (CO23/96/538, 1836, May 17).

In reply, Don Miguel Tacón, the Captain General of Cuba said that he was following the orders of the Spanish Queen and had taken the necessary steps and since the works had started it was too late to stop them (CO23/96/540, 1836, May 18).

The British Admiralty ventured to speculate the reason why Cuba elected to erect the lighthouse on Cay Sal and not Elbow Cay. Lord Minto writes:

The Spanish Authorities persist in the formal occupation of Cay Sal, in which place they are building a lighthouse, where it will be of no use to the general track though extremely convenient to vessels of the Slave Trade.

I would venture to suggest that Vice Admiral, Sir Charles Paget should be instructed to require the immediate removal of the Spaniards from Cay Sal and the entire demolition of the works constructed there (CO23/101/41, 1837, April 12).

Finally, by October 1837, the British Government realized that if a lighthouse was to be built on Elbow Cay they would have to build it themselves. The Lord of the Treasury has Secretary Baring write:

on the subject of a lighthouse which it is proposed to erect on Cay Sal Bank, I am requested that you will state to Viscount Lord Palmerstone that His Lordship is of the opinion that the fact that the English Government building the lighthouse on Elbow Cay will constitute such practical occupation of the Bank as will carry with it the power of protecting the persons and property that may be placed there, the object that communicating appears to have been sufficiently attained; and the lords have already taken the preliminary 
steps with a view to the commencement of the works without any avoidable delay (CO23/101/67, 1837, October 26).

So in the end all three lighthouses were built by Britain. The lighthouse at Hole-in-theWall, Abaco was built in 1836, the lighthouse at Gun Cay, Bimini in 1836 and the Cay Sal lighthouse was built at Elbow Cay in 1839. The next set of lighthouses were built at Great Isaac Cay, Bimini in 1859, Great Sturrup Cay, Berry Islands in 1863, Elbow Cay, Abaco in 1864, Castle Island, Acklins in 1868, Cay Lobos, Jumentos Cays in 1869, Great Inagua in 1870, Bird Rock, Crooked Island in 1876, and Egg Island, Eleuthera in 1891. Seven beacons were also strategically placed in that period and many more lighthouses were built in the 1900s.

The lighthouses were not the only reason for the decline in wrecked ships. During the American Civil War, the blockade of the southern ports by the north disrupted trade. Furthermore, the expansion of the roads, canals and railways from the eastern seaboard ports west provided an alternative means of transportation by land, which was faster and safer. Fewer trading vessels meant fewer wrecks.

The mid-19th century was an era of great technological advancement, which revolutionized navigation in a number of ways. The steam ship supplanted the sailing vessel and no longer was the mariner at the mercy of the elements. Not only were the captains of vessels better trained and the reefs and shoals better charted but also a number of navigational aids made travel by steamer more precise. With the advent of the electric telegraph, the captain and crew were better informed about adverse weather conditions. In addition, the steamships from the eastern seaboard could take a more direct route south. They no longer travelled through the Northeast Providence Channel to get to Nassau or the Gulf but went directly south, hugging the eastern United States coast (Lawlor \& Lawlor, 2008).

It is uncertain when the Cay Sal Bank was formally recognized as a possession of The Bahamas. An 1866 report of the British Government noted that Cay Sal had been "claimed until a few years past, jointly by England and Spain. It has been several times settled by Spanish Colonists. The last of these settlers were driven off by the English twenty-five years ago, and the Island is now recognized by them as English property" (Island of Cay Sal, p. 5). And in 1959 the Cay Sal Bank was recognized by Cuba as belonging to The Bahamas when Fidel Castro suggested that the Cay Sal Banks should be ceded to Cuba as they were underdeveloped and isolated from The Bahamas. Castro felt they would be more useful to Cuba for fishing and tourism (Perez, 2002). 


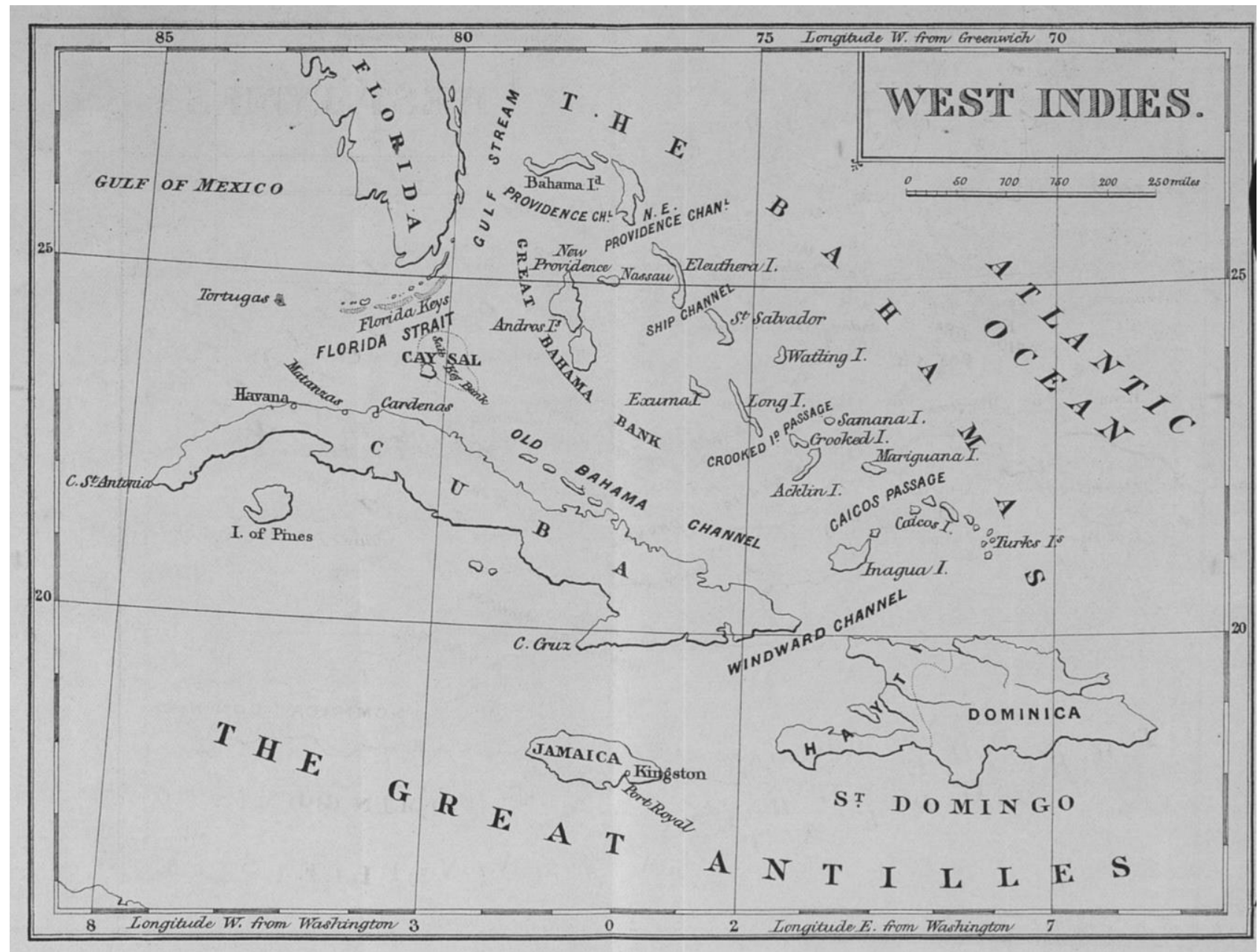

Figure 1. Map showing shipping channels in the Bahamas archipelago. From: Island of Cay Sal, Bahamas, and its commercial importance as a salt depot, 1866, London: John King, p. $5 .$.

\section{Colonial Office Papers}

(available at the Department of Archives, Nassau, Bahamas)

CO23/73/104. (1824, August 13). Governor Lewis Grant to Earl of Bathurst.

CO23/73/105. (1824, March 25). Enactment of a Bill by USA Congress.

CO23/73/23. (1824, March 4). Governor

Grant to Earl of Bathurst.

CO23/76/303-8. (1827, August 12). Louis

Grant to Viscount Goodwich.

CO23/76/411. (1827, December 22).

Governor Grant to General W. Hackinson.
CO23/76/419. (1827, June 29). Governor Grant to Admiral Fleming of Jamaica.

CO23/76/421. (1827, September 6). Vice Admiral Fleming to His Excellency in General Court, Jamaica.

CO23/76/422. (1827, September 3). Vice Admiral Fleming to J. W. Croker.

CO23/76/423. (1827, December 1). Admiral Fleming to General Grant.

CO23/77/5. (1827, October 15). Report of Mr. De Mayne of Royal Navy, (Board of Admiralty).

CO23/78/193. (1827, September 3). Report of G. Murray, Vice Admiralty. 
CO23/81/224. (1828, February 18). William Vesey Munnings to Sir George Murray.

CO23/83/13. (1829, July 30). Sworn before John C. Lees by John Bunch, Bahama Islands, New Providence.

CO23/83/15. (1829, September 10). Sworn before John C. Lees, Bahama Islands, New Providence.

CO23/91/14. (1833, December 27).

Instruction to John Kitson Royal Engineers Office, Nassau, New Providence.

CO23/92/263. (1834, November 8). Madrid, George Villiers to Rt. Hon Lord Viscount Palmerston, New Providence.

CO23/92/266. (1834, June 26). George

Villiers to Don Francisco Martinez de la Rosa, New Providence.

CO23/94/233. (1835, November 13). Lt

Commander Stanley Hornby to Lt. Governor Colebrooke, New Providence.

CO23/95/72. (1835, November 24). New

Providence.

CO23/96/427. (1836, April 28). HM's Ship

Cruiser, at Gun Cay, J. L. Willis, Commander to Lt. Governor Colebrooke, New Providence.

CO23/96/538. (1836, May 17). Captain

Richard Owen to His Excellency, Captain General of Cuba, New Providence.

CO23/96/540. (1836, May 18). Captain

General of Cuba, Don Miguel Tacón to

Captain Richard Owen, New Providence.

CO23/101/41. (1837, April 12). Admiralty, S

Minto to Lord Palmerston, New

Providence.

CO23/101/67. (1837, October 26). Treasury

Chambers, F Baring for attention of

Viscount Palmerston, New Providence.

CO23/192/23. (1836, November 15). Bahama

Argus, Notice to Mariners. New

Providence.

\section{References}

Albury, P. (1984). The Paradise Island story. London: MacMillan Education.

Island of Cay Sal, Bahamas, and its commercial importance as a salt depot. (1866). London: John King. Available at https://www.jstor.org/stable/60229038

Lawlor, A., \& Lawlor, J. (2008). The Harbour Island story. London: MacMillan.

Perez, L. (2002). Preface. Cuban studies, 33, ix. Available at https://www-jstororg.cob.idm.oclc.org/stable/24487782

Richardson, J. D. (1897). Messages and papers of the Presidents: Thomas Jefferson, James Madison, James Monroe, and John Quincy Adams, Vol. 2. New York: Bureau of National Literature.

Shepard, B. (1961). Lore of the wreckers. Boston: Beacon Press. 